Jurnal Ilmiah Potensia, 2019, Vol. 4 (1), 1-5

\title{
MANAJEMEN PENDIDIKAN ANAK USIA DINI PADA PAUD BINTANG RABBANI PEKANBARU
}

\author{
Suharni \\ suharni@unilak.ac.id
}

\begin{abstract}
This study aims to describe the management of early childhood education at Bintang Rabbani ECD. This study uses a qualitative approach and is descriptive. The selection of research subjects was carried out using a purposive sampling technique. Research subjects are managers, educators, students, and parents. Data is collected through observation, interviews, and documentation. Checking the validity of the data is done through diligence of observation, participation, and adequacy of references. The results of the study indicate that the Bintang Rabbani PAUD program management was prepared in accordance with the vision and mission of the institution by implementing management functions including; planning, implementation, supervision and guidance. Managers as leaders in carrying out management functions strongly emphasize cooperation based on sincerity, enthusiasm, and high loyalty. Planning is done with strategic planning, preparation of learning plans ranging from annual, semester, monthly, weekly to daily. Organizing is done by coordinating tasks, opportunities, experiences and insights with open communication, holding regular meetings that discuss efforts to improve performance. Supervision is carried out by direct observation, through supervision, regular meetings with educators. Collaboration is done with parents, through monthly meetings (parenting), and partners related to PAUD. Assessment and evaluation are carried out by giving assignments, observations, diaries, anecdotes, performance, work results, and educational visits.
\end{abstract}

Keywords: Management of Education; Education; Early Childhood.

\section{PENDAHULUAN}

Usia dini merupakan masa kritis bagi pembentukan karakter. Penanaman sikap sejak dini meupakan kunci utama untuk membangun bangsa. Pada usia 0-6 tahun otak berkembang sangat cepat hingga 80 $\%$. Anak-anak adalah generasi yang akan menentukan nasib bangsa dikemudian hari. Masa ini disebut juga dengan periode emas (golden age). Pada masa ini ditandai dengan munculnya masa peka, identifikasi, imitasi, dan eksplorasi anak. Masa ini tidak akan bisa berulang, seyogyanya orangtua memberikan ruang kepada anak dalam melewati masa-masa ini. Salah satunya adalah melalui pembelajaran di lembaga pendidikan anak usia dini yang diistilahkan dengan PAUD.

PAUD tidak ditekankan semata kepada pemberian stimulus pengayaan pengetahuan anak, tetapi lebih diarahkan kepada pengembangan potensi dan daya kreatifitas anak, dan yang sangat penting adalah pada pembentukan sikap mental dan kepribadian anak yang berlandaskan pada nilai-nilai ajaran agama.Sehingga diperlukan suatu tempat yang mewadahi 
anak- anak untuk tumbuh dan berkembang sesuai usianya.

PAUD adalah suatu proses pembinaan tumbuh kembang anak usia dari lahir hingga enam tahun secara menyeluruh, yang mencakup aspek fisik dan non fisik. Perkembangan lembaga-lembaga PAUD di Indonesia mengalami peningkatan yang sangat pesat. Keberadaan lembaga tersebut tidak saja muncul di daerah pusat perkotaan tetapi juga sudah merambah sampai ketingkat pedesaan. Masyarakat juga menyambut baik, hal ini diindikasikan dengan adanya kesadaran orangtua akan pentingnya memberikan rangsangan lebih awal untuk membantu tumbuh kembangnya brbagai potensi anak. Sejalan dengan hal ini perlunya manajemen penyelenggaraan yang dilaksanakan secara profesional, yang ditunjang juga dengan perhatian dari pemerintah. Sehingga tercapailah tujuan pendidikan nasional yakni mencerdaskan kehidupan bangsa.

Manajemen

penyelenggaraan

berkaitan dengan tata laksana dan kelola lembaga, berkaitan dengan pengadministrasian, pengaturan, atau penataan kegiatan di lembaga. Manajemen berasal dari kata to manage yang berarti mengelola, memimpin atau mengarahkan. Manajemen sangat berperan penting dalam sebuah PAUD karena keberhasilan sebuah PAUD tidak lepas dari manajemen yang baik. Menurut Hapidin dkk (2012) Manajemen memiliki makna sebagai usaha mengelola, mengendalikan, dan mengarahkan berbagai sumber yang ada untuk mencapai tujuan yang diharapkan. Manajemen merupakan suatu proses mengkoordinasikan dan mengintegrasikan sumber daya melalui kegiatan-kegiatan agar diselesaikan secara efisien dan efektif dengan melibatkan orang lain.

Sedangkan pendidikan merupakan suatu proses interaksi antara peserta didik dengan pendidikan dan /atau lingkungan yang disadari, teratur, terencana dan sistematis untuk mengembangkan potensi anak secara optimal. Adapun tujuan manajemen pendidikan di PAUD Bintang Rabbani adalah bagaimana lembaga ini memanjemen lembaga dari berbagai aspek yaitu mulai dari sistem pengelolaan, pendidik, karyawan, anak didik,keuangan, sarana dan prasarana serta keluaran yang dihasilkan oleh PAUD. Dari segi manajemen keuangan, PAUD pengelola berusaha mengefisienkan dan meminimalisasi biayabiaya pengeluaran tetapi dengan hasil yang optimal dan mengefektifkan dengan cara mengambil langkah-langkah yang tepat dalam mengambil setiap keputusan sehingga tujuan dapat dicapai sesuai dengan visi dan misi lembaga. Secara teori penelitian ini bermanfaat untuk mengembangkan konsep manajemen PAUD menjadi lebih baik secara efektif dan efisien. Secara praktis diharapkan mampu memberikan acuan dalam merumuskan dalam meningkatkan mutu program PAUD.

\section{METODE}

Penelitian ini menggunakan pendekatan kualitatif dan bersifat deskriptif. Pemilihan subjek penelitian dilakukan dengan menggunakan teknik purposive sampling. Cara pengambilan sampel ini sengaja yaitu peneliti menentukan sendiri sampel yang diambil dengan pertimbangan tertentu. Subjek penelitian adalah pengelola, pendidik, anak didik, dan orangtua. Data dikumpulkan melalui observasi, wawancara, dan dokumentasi. Pengecekan keabsahan data dilakukan melalui ketekunan pengamatan,keikutsertaan, dan kecukupan referensi. Trianto (2011: 315) menyatakan bahwa observasi adalah cara pengumpulan data melalui pengamatan langsung terhadap sikap, perilaku, dan berbagai kemampuan yang ditunjukkan anak. Sedangkan Mulyasa (2012: 199) mendefinisikan observasi sebagai cara 
pengumpulan data untuk mendapatkan informasi melalui pengamatan langsung terhadap sikap dan perilaku anak. Observasi tidak hanya dilakukan disekolahkan namun dapat juga dilakukan sesuai dengan kebutuhan penelitian.

Selain itu wawancara juga merupakan alat yang penting untuk mengambil data dalam sebuah penelitian. Wawancara digunakan sebagai teknik pengmpulan data apabila penelitian melakukan studi pendahuluan untuk menemukan permasalahan yang harusditeliti dan apabila peneliti ingin mengetahui hal dari responden secara lebih mendalam.

Menurut Sugiono (2012: 72) berpendapat bahwa wawancara merupakan pertemuan dua orang untuk bertukar informasi dan ide melalui tanya jawab sehingga dapat dikonstruksikan makna dalam suatu topik tertentu. Wawancara sangat penting untuk mendapat informasi yang akurat sehingga dapat digunakan dalam keabsahan yang akurat.

Sedangkan menurut Moleong (2010: 186), wawancara adalah percakapan dengan maksud tertentu, yang dilakukan oleh dua pihak yaitu orang yang mengajukan pertanyaan (pewawancara) dan orang yang menjawab pertanyaan (terwawancara).

Dalam penelitian ini, peneliti menggunakan teknik wawancara untuk menggali informasi guna memperoleh data yang berkaitan dengan perkembangan anak dan implementasi pembelajaran. Adapun sumber wawancaranya adalah guru kelas dan pengelola PAUD Bintang Rabbani.

Dokumentasi tentang manajemen penyelengaraan dan pengelolaan di PAUD Bintang Rabbani :
a. Dokumen yang berupa Rencana Kegiatan Harian.
b. Dokumen yang berupa kurikulum K13
c. Dokumen berupa MOU.

d. Dokumentasi berupa foto dan rekaman video kegiatan pembelajaran pada anak PAUD Bintang Rabbani.

Menurut Sugiyono (2012: 82), dokumen merupakan catatan peristiwa yang sudah berlalu bisa berbentuk tulisan, gambar, atau karya-karya monumental.

\section{HASIL DAN PEMBAHASAN}

Hasil penelitian menunjukkan bahwa manajemen program PAUD Bintang Rabbani disusun sesuai dengan visi dan misi lembaga dengan menerapkan fungsi-fungsi manajemen meliputi; perencanaan, pelaksanaan, pengawasan dan pembinaan. Pengelola sebagai pimpinan dalam menjalankan fungsi-fungsi manajemen sangat menekankan kerjasama didasari keikhlasan, semangat,dan loyalitas yang tinggi.Perencanaan dilakukan dengan perencanaan strategik, penyusunan rencana pembelajaran mulai dari tahunan, semester, bulanan, mingguan sampai harian. Pengorganisasian dilakukan dengan koordinasi tugas, kesempatan, pengalaman dan wawasan dengan komunikasi terbuka, mengadakan pertemuan rutin yang membahas upaya peningkatan kinerja. Pengawasan dilakukan dengan observasi langsung, melalui supervisi, rapat rutin dengan pendidik. Kerjasama dilakukan dengan orangtua, melalui kegiatan pertemuan bulanan (parenting), dan mitra terkait PAUD. Penilaian dan evaluasi dilaksanakan dengan pemberian tugas, observasi, catatan harian, anekdot, unjuk karya, hasil karya, dan kunjungan edukasi serta informasi perkembangan melalui catatan kesehatan anak didik. Menurut Suharti (2018: 1) fasilitas dan infastruktur yang baik sangat berperan penting dalam kemajuan sebuah sekolah sehingga dapat memberikan kenyaman untuk anak dalam pembelajaran. Pada fasilitas sarana dan sarana sangat diperhatikan keselamatan, 
peraturan yang berlaku serta standart yang ditentukan oleh pemerintah. Sarana dan prasarana yang tersedia berupa sarana in door dan out door sebagai alat pembelajaran anak didiksesuai dengan tingkat perkembangan anak didik. Sejalan dengan pendapat Darmayanti (2017 :8) tanpa sarana dan prasarana yang memadai akan menghambat proses pembelajaran indoor maupun outdoor. Hal tersebut menjelaskan bahwa saran dan prasarana menjadi penunjang penting dalam berbagai aspek sehingga anak lebih bersemangat dalam bermain dalam pembelajaran dengan fasilitas yang lengkap dan memadai.

Salah satu unsur adanya lembaga pendidikan yang harus dipenuhi adalah adanya peserta didik. Dalam hal ini di PAUD Bintang Rabbani peserta didik dikelompokkan berdasarkan usia yaitu :

- Usia 2-4: Kelompok C

- Usia 4-5 : Kelompok A

- Usia 5-6 : Kelompok B

Untuk alokasi waktu disesuaikan dengan usia yakni :

- Kelompok 2-4 tahun : Satu kali pertemuan selama 150 - 180 menit

- Kelompok 4-6 tahun : satu kali pertemuan : 180 menit

Perbandingan antara pendidik dengan peserta didik :

- Kelompok 2-4 : 1: 10 anak

- Kelompok 4-6 tahun : 1 : 15 anak

Sedangkan Kurikulum yang digunakan di PAUD Bintang Rabbani adalah kurikulum K-13yang mana dalam pengembangan kurikulum terdapat pendekatan saintifik. Dengan tujuan bagaimana anak mampu menolong dirinya sendiri pada semua aspek kehidupan (lifes skill) dan menanamkan kebiasaan tentang belajar bagaimana seharusnya belajar (Learning to learn). Perubahan kurikulum juga tidak terlepas dari peran para pengambil kebijakan yakni pemerintah terkait di bidang pendidikan.
Pada K-13 adanya standar yang menjadi acuan dalam konsep dasar dan pembelajaran pada anak, meliputi dalam hal :

1. Ketercapaian Tingkat Pencapaian Perkembangan Anak Usia Dini

2. Berorientasi pada hasil belajar

3. Menggunakan pendekatan metode yang bervariasi

4. Sumber belajar tidak terfokus pada guru, tetapi berpusat pada anak.

5. Penilaian lebih ditekankan pada proses yang terjadi selama kegiatan berlangsung dan bukan pada hasil belajar (berkelanjutan).

Ada beberapa kelebihan yang dimiliki dalam pembelajaran pada K-13 sehingga sampai saai ini masih menjadi acuan, diantaranya :

a. Kurikulum 2013 mencakup pengembangan pada aspek sruktur kurikulum, proses pembelajaran dengan pendekatan saintifik dan penilaian yang bersifat otentik.

b. Kurikulum ini mengusung pengembangan pembelajaran yang bersifat konstruktif yang lebih fleksibel sehingga memberi ruang pada anak untuk mengembangakan bakat dan potensinya.

c. Model pendekatan kurikulum bertujua membentuk sikap, pengetahuan, dan keterampilan peserta didik yang lebih konsisten dan fundamental bagi peserta didik agar lebih siap melanjutkan ke jenjang pendidikan yang lebih tinggi.

d. Kelas bukan satu-satunya tempat belajar

e. Sumber belajar bukan hanya guru dan buku.

f. Belajar dengan berkreativitas

g. Mengajak anak jeli terhadap rasa keingintahuannya

h. Membuat anak suka bertanya karena keingintahuannya 
i. Mengajak siswa mencari tahu bukan diberitahu.

j. Melatih kepemimpinan

k. Menyadari siswa memiliki khas

I. Mendahulukan pemahaman Bahasa.

Kurikulum 2013 Pendidikan Anak Usia Dini dikembangkan dengan berlandaskan pada berbagai kajian, baik secara teoretis, empiris, yuridis, maupun sosial budaya. Program pembelajaran meliputi 6 aspek yaitu nilai agama dan moral, kognitif, sosial emosional, bahasa, fisik motorik, dan seni, yang disesuaikan dengan Standar Tingkat Pencapaian Perkembangan Anak (STPPA).

\section{PENUTUP}

Simpulan

Manajemen memiliki makna sebagai usaha mengelola, mengendalikan, dan mengarahkan berbagai sumber yang ada untuk mencapai tujuan yang diharapkan. Di PAUD Bintang Rabbani manajemen pendidikan sudah dilakukan melalui tahapan meliputi; perencanaan, pelaksanaan, pengawasan dan pembinaan dan sebagian besar sudaj berjalan dengan baik.

\section{Saran}

1. Hendaknya semua komponen di PAUD bersinergi baik pengelola, pendidik, anak didik, orangtua dan mitra terkait guna menghasilkan kualitas pendidikan yang lebih baik.

2. Diharapkan dengan penelitian ini dapat memberikan masukan untuk pengelola, guru serta peneliti berikutnya sehingga dapat dilakukan lebih baik lagi.

\section{DAFTAR PUSTAKA}

Darmayanti. Mursalina 2016. Manajemen Program Satuan Di PAUD SPS Edelweis Kelurahan Tridadi Sleman Yogyakarta. UNY. Yogyakarta.

Hapidin (2012) Manajemen Pendidikan TK/PAUD. Universitas Terbuka : Tangerang Selatan.
J.Moleong. Lexy. (2007). Metodologi Penelitian Kualitatif. Bandung. Rosdakarya.

Mulyana, Dedy. (2012). Metodologi Penelitian Kualitatif Paradigma Baru Ilmu Komunikasi Dan Ilmu Sosial Lainnya. Bandung : PT Remaja Rosdakarya.

Sugiono. (2012). Metode Penelitian Kuantitatif, kualitatif, dan $R \& D$. Cetakan ke-17. Bandung : Alfabeta.

Suharti. (2018). Manajemen Pendidikan Anak Usia Dini Dalam Rangka Meningkatkan Mutu Pembelajaran ( Studi Kasus Pada PAUD Negeri Pembina Curup Dan PAUD Pertiwi Rejang Lebong. Jurnal Studi Manajemen Pendidikan. Vol. 2. No. 1. STAIN. Curup.

Trianto. (2011). Desain Pengembangan Tematik Bagi Anak Usia Dini TK/RA \& Anak Usia Kelas Awal SD/MI. Jakarta : Kencana. 